\title{
Antibacterial, chemical and physical properties of sealants with polyhexamethylene guanidine hydrochloride
}

Isadora Martini GARCIA(a)

Stéfani Becker RODRIGUES(a)

Vicente Castelo Branco LEITUNE(a)

Fabrício Mezzomo COLLARES(a) iD

(a) Universidade Federal do Rio Grande do Sul-UFRGS, School of Dentistry, Dental Materials Laboratory, Porto Alegre, RS, Brazil.
Declaration of Interests: The authors certify that they have no commercial or associative interest that represents a conflict of interest in connection with the manuscript.

\section{Corresponding Author:}

Fabrício Mezzomo Collares

E-mail: fabricio.collares@ufrgs.br

htrps://doi.org/10.1590/1807-3107bor-2019.vol33.0019
Abstract: The aim of this study was to evaluate the influence of polyhexamethylene guanidine hydrochloride (PHMGH) in the physicochemical properties and antibacterial activity of an experimental resin sealant. An experimental resin sealant was formulated with $60 \mathrm{wt} . \%$ of bisphenol A glycol dimethacrylate and $40 \mathrm{wt} . \%$ of triethylene glycol dimethacrylate with a photoinitiator/co-initiator system. PHMGH was added at $0.5\left(\mathrm{G}_{0.5 \%}\right), 1\left(\mathrm{G}_{1 \%}\right)$, and $2\left(\mathrm{G}_{2 \%}\right)$ wt. \% and one group remained without PHMGH, used as control $\left(\mathrm{G}_{\mathrm{CTRL}}\right)$. The resin sealants were analyzed for degree of conversion (DC), Knoop hardness (KHN), and softening in solvent $(\triangle \mathrm{KHN})$, ultimate tensile strength (UTS), contact angle $(\theta)$ with water or $\alpha$-bromonaphthalene, surface free energy (SFE), and antibacterial activity against Streptococcus mutans for biofilm formation and planktonic bacteria. There was no significant difference for DC ( $p>0.05)$. The initial Knoop hardness ranged from $17.30( \pm 0.50)$ to $19.50( \pm 0.45)$, with lower value for $G_{\text {CTRL }}(p<0.05)$. All groups presented lower KHN after immersion in solvent $(\mathrm{p}<0.05)$. The $\Delta \mathrm{KHN}$ ranged from $47.22( \pm 4.30)$ to $57.22( \pm 5.42) \%$, without significant difference $(\mathrm{p}>0.05)$. The UTS ranged from $54.72( \pm 11.05) \mathrm{MPa}$ to $60.46( \pm 6.50)$ $\mathrm{MPa}$, with lower value for $\mathrm{G}_{2 \%}(\mathrm{p}<0.05)$. PHMGH groups presented no significant difference compared to $G_{\text {CTRL }}$ in $\theta$ ( $p>0.05$ ). $G_{2 \%}$ showed no difference in SFE compared to $G_{\text {CTRL }}(p>0.05)$. The groups with PHMGH presented antibacterial activity against biofilm and planktonic bacteria, with higher antibacterial activity for higher PHMGH incorporation ( $p$ $<0.05)$. PHMGH provided antibacterial activity for all resin sealant groups and the addition up to $1 \mathrm{wt} . \%$ showed reliable physico-chemical properties, maintaining the caries-protective effect of the resin sealant over time.

Keywords: Pit and Fissure Sealants; Methacrylates; Polymerization; Anti-Bacterial Agents.

\section{Introduction}

Caries recurrence is one of the major causes of restoration failure and restoration replacement in the long term. ${ }^{1}$ The incorporation of antibacterial agents in restorative materials have been studied, aiming 
to develop therapeutic materials with improved biological properties. ${ }^{2,3,4,5,6,7}$. Resin sealants for pits and fissures, applied to prevent new caries lesions ${ }^{8}$ and to arrest non-cavitated lesions, ${ }^{9}$ wear and detach over tim $\mathrm{e}^{10}$ with consequent biofilm formation around the sealant/enamel interface, increasing the risk of recurrent caries. ${ }^{11}$

To overcome this issue, the incorporation of fillers in resin sealants have been used to improve the acid- and caries-resistance of dental tissue. Sodium monofluorophosphate, ${ }^{12}$ nylon- 6 and chitosan, ${ }^{13}$ fluoroboroaluminosilicate glass, ${ }^{14}$ and Bioglass $45 S 5^{15,16}$ were already tested. In addition, enamel pre-treatments, such as $45 \mathrm{~S} 5$ bioactive glass airabrasion, done before sealant application, have been evaluated, improving enamel etchability and reducing microleakage. ${ }^{16}$ Nevertheless, the incorporation of inorganic fillers may negatively affect the rheological properties of resins ${ }_{1}^{17}$ compromising polymer chain mobility and sealing properties, ${ }^{12}$ and decreasing the degree of conversion. ${ }^{18}$

Polyhexamethylene guanidine hydrochloride (PHMGH) is an organic compound from guanidine family with cationic charge ${ }^{19}$ and broad-spectrum antimicrobial activity against Gram-positive and Gram-negative bacteria ${ }^{19,20,21}$ and fungi. ${ }^{22}$ Compared to other disinfectants, such as chlorhexidine digluconate, PHMGH presents higher antimicrobial activity against ESKAPE pathogens (Enterococcus faecium, Staphylococcus aureus, Klebsiella pneumoniae, Actinetobacter baumannii, Pseudomonas aeruginosa and Enterobacter species), which are clinically important antibiotic-resistant microorganisms. ${ }^{20}$ PHMGH has shown to be an effective sporicidal at low concentration, killing spores of Gram-positive bacteria at $0.52 \%(w / v)$ in 90 seconds and $0.36 \%(\mathrm{w} / \mathrm{v})$ in three minutes. ${ }^{19}$ Therefore, it has been used as one of the major components of Akacid plus ${ }^{\circledR}$, a disinfectant widely recommended for hospital and household use, besides its usage in the food and drug industries, due to its colorless and odorless qualities. ${ }^{19,21}$ However, there is no report about the use of PHMGH against Streptococcus mutans or in dental materials. Polyhexamethylene guanidine may have toxic effects, such as causing pulmonary fibrosis, when used in humidifier disinfectants. ${ }^{23}$ Other studies showed that PHMGH presented lower cytotoxic effects against human cells than commonly used antimicrobial agents such as chlorhexidine and quaternary ammonium compounds. ${ }^{24}$

The incorporation of PHMGH into resin sealants could result in a material with antibacterial properties without affecting other properties. ${ }^{2,7}$ The aim of this study was to evaluate the influence of PHMGH in the physico-chemical properties and antibacterial activity of an experimental resin sealant. The null hypothesis tested for the present study was that the addition of PHMGH does not influence the resin sealant properties.

\section{Methodology}

\section{Formulation of experimental resin sealants}

Bisphenol A glycol dimethacrylate (BisGMA, Aldrich Chemical Company, St. Louis, Missouri, USA) at $60 \mathrm{wt} . \%$ and triethylene glycol dimethacrylate (TEGDMA, Aldrich Chemical Company, St. Louis, USA) at $40 \mathrm{wt}$.\% were hand-mixed for $5 \mathrm{~min}$, sonicated for $180 \mathrm{~s}$ and hand-mixed again for $5 \mathrm{~min}^{25}$. A photoinitiator /co-initiator system composed by Camphorquinone (CQ, Aldrich Chemical Company, St. Louis, USA) and ethyl 4-dimethylaminobenzoate (EDAB, Aldrich Chemical Company, St. Louis, USA) added at $1 \mathrm{~mol} \%$, according to BisGMA and TEGDMA moles ${ }^{13}$. Polyhexamethylene guanidine hydrochloride (PHMGH), Figure 1, was incorporated at $0.5\left(\mathrm{G}_{0.5 \%}\right)$, $1\left(\mathrm{G}_{1 \%}\right)$, and $2\left(\mathrm{G}_{2 \%}\right) \mathrm{wt} . \%$ in the resin sealant for test groups and one group, without PHMGH, was used as control $\left(\mathrm{G}_{\mathrm{CTRL}}\right)$. For experimental resin sealants formulation, all components were weighed with an analytical balance (AUW220D, Shimadzu, Kyoto, Kyoto, Japan). A light-emitting diode (Radii Cal, SDI, Australia) at $1200 \mathrm{~mW} / \mathrm{cm}^{2}$ was used for photoactivation.

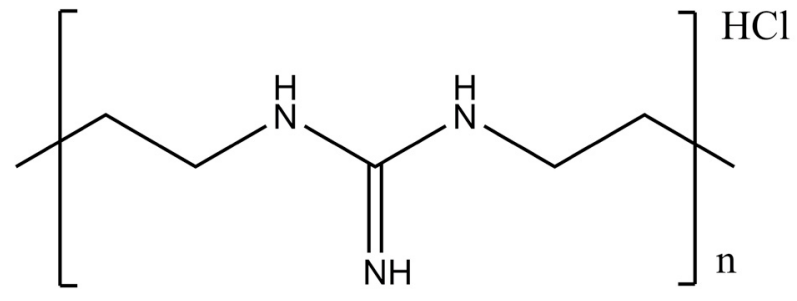

Figure 1. Polyhexamethylene guanidine hydrochloride (PHMGH) representation. 


\section{Degree of conversion}

For degree of conversion (DC) assessment, three samples per group, $\mathrm{n}=3$, were evaluated by FTIRATR (Vetrex 70, Bruker Alpha, Ettingen, Germany). The resin sealants were dispensed onto the ATR crystal in a polyvinylsiloxane matrix with $1 \mathrm{~mm}$ thickness measured using a digital caliper. The uncured resin sealant was positioned on ATR in the polyvinylsiloxane matrix. The resin sealants were photoactivated for $50 \mathrm{~s}$ with the tip of the LED unit fixed by a device at $1 \mathrm{~mm}$ from the top of each specimen. The polymerized samples were then measured using a digital caliper. Data were evaluated with Opus 6.5 software (Bruker Optics, Ettlingen, Germany) with Blackman Haris 3-Term apodization, in $4000-400 \mathrm{~cm}^{-1}$ range with 64 scans at $4 \mathrm{~cm}^{-1}$ resolution. Spectra were obtained before and after polymerization and the DC was calculated considering the intensity of carbon-carbon double bond stretching vibration (peak at $1640 \mathrm{~cm}^{-1}$ ) using the aromatic carbon-carbon double bond stretching vibration (peak at $1610 \mathrm{~cm}^{-1}$ ) from the polymerized and unpolymerized samples as internal standard. ${ }^{26}$

\section{Softening in solvent}

The softening in solvent of experimental resin sealants was evaluated with five samples per group ( $\mathrm{n}=5,1.0 \mathrm{~mm}$ of thickness $\times 4.0 \mathrm{~mm}$ of diameter) photoactivated for $30 \mathrm{~s}$ on each side. The samples were embedded in an acrylic resin to be polished (Model 3v, Arotec, Cotia, Brazil) with silicon carbide sandpapers (1000, 1200, and 2000-grit) and a felt disc saturated with $0.5-\mu \mathrm{m}$ alumina suspension. After 24 $\mathrm{h}$, five indentations ( $10 \mathrm{~g}$ for $5 \mathrm{~s}$ ) were performed on each sample using a microhardness tester (HMV 2; Shimadzu, Tokyo, Japan) to obtain the initial Knoop hardness number (KHN1). The samples were immersed in a solution of ethanol:water (70:30) for $2 \mathrm{~h}$, washed with distilled water, and evaluated to obtain the final Knoop hardness number (KHN2). The percentage difference between KHN1 and KHN2 was calculated $(\Delta \mathrm{KHN} \%)$ for each group. ${ }^{27}$

\section{Ultimate tensile strength}

For the ultimate tensile strength (UTS), ten samples per group, $\mathrm{n}=10$, were prepared using a metallic matrix (hourglass-shaped with $8.0 \mathrm{~mm}$ long $\times 2.0$ $\mathrm{mm}$ wide $\times 1.0 \mathrm{~mm}$ thickness) with a cross-sectional area of $1 \mathrm{~mm}^{2}$ at the constriction. The samples were photoactivated for $30 \mathrm{~s}$ on each side. After $24 \mathrm{~h}$, the samples were fixed in a metallic device with cyanoacrylate resin and submitted to microtensile strength in a universal testing machine (EZ-SX Series, Shimadzu, Kyoto, Japan) at a crosshead speed of 1 $\mathrm{mm} / \mathrm{min}$; the values were reported in $\mathrm{MPa}{ }^{28}$

\section{Contact angle and surface free energy}

For contact angle and surface free energy evaluation, three samples per group, $\mathrm{n}=3$, were prepared ( $1.0 \mathrm{~mm}$ of thickness $\times 5.0 \mathrm{~mm}$ of diameter) with photoactivation for $30 \mathrm{~s}$ on each side. The samples were analyzed by an optical tensiometer Theta (Biolin Scientific, Stockholm, Sweden) to evaluate the contact angle $(\theta)$ between the samples' surface and a drop of distilled water (polar liquid) or $\alpha$-bromonaphthalene (non-polar liquid). The surface free energy (SFE) was assessed by the sessile drop method. The drop out size was $3.0 \mu \mathrm{L}$, the drop rate was $2.0 \mu \mathrm{L} / \mathrm{s}$, the displacement rate was $20.0 \mu \mathrm{L} / \mathrm{s}$, and the speed dispersion of the liquids was $50 \mathrm{~mm} / \mathrm{min}$. The evaluation was performed during $20 \mathrm{~s}$ and the static $\theta$ between each drop and the polymer surface was measured at $10 \mathrm{~s}$. The SFE was achieved using the Owens-Wendt-Rabel-Kaelble (OWRK) method as previously reported ${ }^{3}$ and OneAttension software (Biolin Scientific, Stockholm, Sweden).

\section{Evaluation of antibacterial activity against biofilm formation}

To evaluate the antibacterial activity against biofilm formation, a direct contact inhibition analysis was performed using three samples $(n=3,1.0 \mathrm{~mm}$ thickness $x 4.0 \mathrm{~mm}$ diameter) per group, photoactivated for 30 $\mathrm{s}$ on each side. The samples were attached on the lid of a test plate and the assembly was submitted to hydrogen peroxide plasma (58\%) sterilization for 48 $\mathrm{min}$ at $56^{\circ} \mathrm{C}$. Each well of a 48 -well plate contained $900 \mu \mathrm{L}$ of brain-heart infusion broth (Aldrich Chemical Co., St. Louis, Missouri, USA), 1 wt.\% sucrose, and $100 \mu \mathrm{L}$ of Streptococcus mutans (NCTC 10449) at 107 CFU/ $\mathrm{mL}$ suspension from an overnight broth culture. The 48-well plate was incubated with the assembly (lid 
and samples) at $37^{\circ} \mathrm{C}$ for $24 \mathrm{~h}$. Three wells with broth and Streptococcus mutans but without samples were used as negative control. The samples were removed from the lid and vortexed for $1 \mathrm{~min}$ in $1 \mathrm{~mL}$ of saline solution $(0.9 \%)$ to be diluted until $10^{-6}$ dilution. Two $25-\mu \mathrm{L}$ drops of each dilution were platted in brainheart infusion agar Petri dishes and incubated at $37^{\circ} \mathrm{C}$ for $48 \mathrm{~h}$. The number of colony forming units (CFUs) was visually counted and transformed to log $\mathrm{CFU} / \mathrm{mL}^{4}{ }^{4,29,30,31}$

\section{Evaluation of antibacterial activity against planktonic bacteria}

For the evaluation of antibacterial activity against planktonic bacteria, $100 \mu \mathrm{L}$ of each well from the direct contact inhibition assay $(n=3)$ were vortexed in 900 $\mu \mathrm{L}$ of saline solution $(0.9 \%)$, diluted until $10^{-6}$ dilution, and platted in brain-heart infusion agar Petri dishes as previously described. The number of CFUs was visually counted and transformed to $\log \mathrm{CFU} / \mathrm{mL}$.

\section{Statistical analysis}

Statistical analysis was performed using SigmaPlot (version 12.0, Systat Software Inc., USA). Data distribution was evaluated by Shapiro-Wilk test.
Paired t-test was used to compare KHN1 and KHN2 in each group at a level of 0.05 of significance. Oneway ANOVA and Tukey's post-hoc test were used to compare groups in softening in solvent, DC, UTS, contact angle, SFE, antibacterial activity against biofilm and against planktonic bacteria among groups at a level of 0.05 of significance.

\section{Results}

Table 1 presents the DC, KHN1, KHN2, and $\Delta \mathrm{KHN} \%$ results for the experimental resin sealants. The values of DC ranged from $60.29( \pm 3.50)$ to 63.04 $( \pm 0.65) \%$, without significant difference among groups $(\mathrm{p}>0.05)$. The groups with PHMGH incorporation reached higher values of KHN1 compared to control $(p<0.05)$. All groups presented a decrease in Knoop hardness after $2 \mathrm{~h}$ immersed in an ethanolic solution $(\mathrm{p}<0.05)$. The $\Delta \mathrm{KHN} \%$ ranged from $47.22( \pm 4.30)$ to $57.22( \pm 5.42) \%$, without significant difference among groups $(\mathrm{p}>0.05)$.

Table 2 presents the values of UTS, contact angle with water or $\alpha$-bromonaphthalene, and SFE. The UTS ranged from $48.40( \pm 11.00)$ to $60.46( \pm 6.50)$ $\mathrm{MPa}$, without significant difference up to $1 \mathrm{wt} . \%$ of

Table 1. Mean and standard deviation of degree of conversion (DC) after $50 \mathrm{~s}$ of photoactivation, initial Knoop hardness number $(\mathrm{KHN} 1)$, final Knoop hardness number (KHN2) and percentage of microhardness variation ( $\triangle \mathrm{KHN} \%)$ of experimental resin sealants.

\begin{tabular}{lcccc}
\hline Groups & DC $(\%)$ & KHN1 & KHN2 & $\Delta K H N(\%)$ \\
\hline$G_{\text {CTRL }}$ & $61.69( \pm 0.72)^{\mathrm{A}}$ & $17.30\left( \pm 0.50^{\mathrm{B} a}\right.$ & $7.40( \pm 0.86)^{\mathrm{b}}$ & $57.22( \pm 5.42)^{\prime} \mathrm{A}$ \\
$\mathrm{G}_{0.5 \%}$ & $60.73( \pm 1.82)^{\mathrm{A}}$ & $18.81( \pm 0.90)^{\mathrm{Aa}}$ & $9.60( \pm 1.40)^{\mathrm{b}}$ & $49.10( \pm 7.20)^{\mathrm{A}}$ \\
$G_{1 \%}$ & $60.29( \pm 3.50)^{\mathrm{A}}$ & $19.50\left( \pm 0.45^{\mathrm{A}} \mathrm{a}\right.$ & $10.30( \pm 0.93)^{\mathrm{b}}$ & $47.22\left( \pm 4.30^{\prime} \mathrm{A}\right.$ \\
$G_{2 \%}$ & $63.04( \pm 0.65)^{\mathrm{A}}$ & $18.61( \pm 0.73)^{\mathrm{Aa}}$ & $9.00( \pm 1.42)^{\mathrm{b}}$ & $52.00( \pm 6.32)^{\mathrm{A}}$ \\
\hline
\end{tabular}

Different capital letters indicate statistical difference in the same column $(\mathrm{p}<0.05)$. Different small letters indicate statistical difference in the same row $(p<0.05)$. $p$-value of normality test of $D C p=0.343 ; K H N 1 p=0.219 ; K H N 1$ and $K H N 2$ of $G_{\text {CTRL }^{-}} p=0.282 ; G_{0.5 \%}-p=0.739$; $G_{1} \%-p=0.807 ; G_{2} \%-p=0.319$.

Table 2. Mean and standard deviation of ultimate tensile strength (UTS), contact angle ( $\theta$ ) with water and $\alpha$-bromonaphtalene, and surface free energy (SFE) of experimental resin sealants.

\begin{tabular}{lcccc}
\hline \multirow{2}{*}{ Groups } & UTS $(\mathrm{MPa})$ & Water & Contact angle & \multirow{2}{*}{ SFE $(\mathrm{mN} / \mathrm{M})$} \\
\cline { 3 - 4 } $\mathrm{G}_{\mathrm{CTRL}}$ & $60.46( \pm 6.50)^{\mathrm{A}}$ & $67.90( \pm 6.03)^{\mathrm{AB}}$ & $18.11( \pm 6.33)^{\mathrm{A}}$ & $50.00( \pm 2.04)^{\mathrm{A}}$ \\
$\mathrm{G}_{0.5 \%}$ & $54.72( \pm 11.05)^{\mathrm{AB}}$ & $74.20( \pm 4.54)^{\mathrm{A}}$ & $19.80( \pm 4.83)^{\mathrm{A}}$ & $46.95( \pm 1.83)^{\mathrm{B}}$ \\
$\mathrm{G}_{1 \%}$ & $57.43( \pm 7.09)^{\mathrm{AB}}$ & $74.80( \pm 2.90)^{\mathrm{A}}$ & $19.23( \pm 2.80)^{\mathrm{A}}$ & $46.82( \pm 1.20)^{\mathrm{B}}$ \\
$\mathrm{G}_{2 \%}$ & $48.40( \pm 11.00)^{\mathrm{B}}$ & $64.80( \pm 2.33)^{\mathrm{B}}$ & $21.64( \pm 7.10)^{\mathrm{A}}$ & $50.60( \pm 1.23)^{\mathrm{A}}$ \\
\hline
\end{tabular}

Different letters indicate statistical difference in the same column $(p<0.05)$. $p$-value of normality test of UTS $p=0.484$; contact angle with water $p=0.478$; contact angle with $\alpha$-bromonaphtalene $p=0.356$; surface free energy with water $p=0.664$. 
PGMGH compared to $\mathrm{G}_{\mathrm{CTRL}}(\mathrm{p}>0.05)$. There was no significant difference for PHMGH groups compared to $G_{\text {CTRL }}$ for the contact angle with water $(p>0.05)$ and $\alpha$-bromonaphthalene $(p>0.05)$. The SFE ranged from $46.82( \pm 1.20)$ to $50.60( \pm 1.23) \mathrm{mN} / \mathrm{M}$, without significant difference between $\mathrm{G}_{2 \%}$ and $\mathrm{G}_{\mathrm{CTRL}}(\mathrm{p}>0.05)$; lower values were found for $G_{0.5 \%}$ and $G_{1 \%}$ compared to control and $G_{2 \%}(p<0.05)$, which did not differ between them $(p>0.05)$.

Table 3 shows the results of antibacterial activity against biofilm formation on polymerized samples and against planktonic bacteria. With the increase of PHMGH concentration, higher antibacterial activity against biofilm formation was found $(p<0.05)$. The evaluation in planktonic bacteria showed that the $\mathrm{G}_{\text {CTRL }}$ presented no significant difference to the negative control ( $p>0.05)$. $G_{1 \%}$ and $G_{2 \%}$ showed less planktonic bacteria than $\mathrm{G}_{\mathrm{CTRL}}$ and $\mathrm{G}_{0.5 \%}(\mathrm{p}<0.05)$.

\section{Discussion}

In the last major study about prevalence and incidence of oral health conditions, the 2015 Global Burden of Disease (GBD) Study, it was observed that untreated caries in permanent teeth affected more than 2.5 billion people ( $95 \%$ uncertainty interval (UI): 2.4-2.7 billion) and 573 million children, making caries the most prevalent disease in the world. ${ }^{32}$ In addition, in the last estimation for direct and indirect costs due to dental diseases, untreated caries was the cause of $12 \%$ of global productive losses and considered one of the major global public health challenges ${ }^{32}$. Resin sealants are effective in preventing caries lesions. ${ }^{8,33}$ However, the rate of intact sealants decreases over time (73.3\% after 5 years), ${ }^{34}$ negatively impacting their protective effect. ${ }^{11}$ In the present study, PHMGH was incorporated as an antibacterial agent in an experimental resin sealant. The addition of up to $1 \mathrm{wt}$.\% PHMGH showed reliable physicochemical properties and all PHMGH groups showed antibacterial activity against biofilm formation and planktonic bacteria of Streptococcus mutans. Thus, the null hypothesis proposed for the study was rejected.

The experimental resin sealants were evaluated regarding DC, determined as the conversion of unsaturated carbon-carbon double bonds in saturated bonds of monomers. High DC is associated with better mechanical properties ${ }^{26}$ and the addition of different compounds in polymers may decrease the DC by altering chain mobility, ${ }^{12}$ light transmission, ${ }^{18}$ or degree of functionality (number of carbon double bonds). ${ }^{26} \mathrm{PHMGH}$ is a polymer with a short alkyl chain composed by seven carbon atoms with saturated bonds. There was no significant difference in the DC among groups even with lower degree of functionality in $\mathrm{PHMGH}$ groups (there was less $\mathrm{C}=\mathrm{C}$ per volume in PHMGH groups compared to $\mathrm{G}_{\text {CTRL }}$ ). In addition, all groups achieved more than $60 \% \mathrm{DC}$, which is in accordance with the values of commercial resin sealants. ${ }^{35}$ PHMGH presents structural analogies with polymers and quaternary ammonium compounds, which have already been tested in dental resins, especially adhesive resins. Compounds such as 12-methacryloyloxydodecylpyridinium bromide, $^{35}$ 1,3,5-triacryloylhexahydro-1,3,5triazine, ${ }^{7}$ 2-methacryloyloxy ethyl trimethyl ammonium chloride, ${ }^{2}$ and dimethylaminododecyl methacrylate $^{36}$ generally present no influence in the DC at low concentrations (up to $10 \mathrm{wt} . \%$, generally being tested up to $5 \mathrm{wt}$.\%). The short alkyl chain

Table 3. Mean and standard deviation of direct contact inhibition assay in logarithmic transformation of colony forming units per

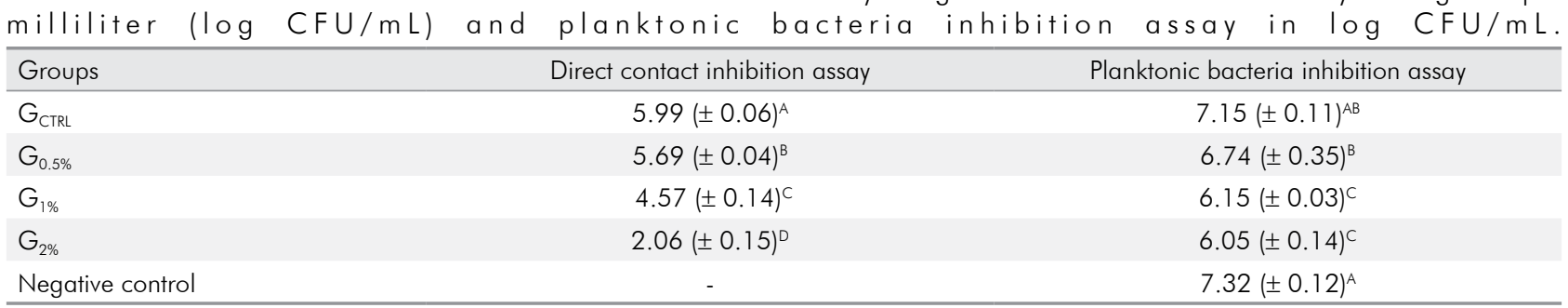

Different capital letters indicate statistically significant difference in the same column $(p<0.05)$. $p$-value of normality test of direct contact inhibition assay $p=0.499$ and planktonic bacteria inhibition assay $p=0.407$. 
of PHMGH contributes to a suitable DC due to the greater chain mobility of the base resin compared to resins with quaternary ammonium compounds with longer alkyl chain. ${ }^{37}$ Furthermore, the refractive index of PHMGH (poly (hexamethylene biguanide) hydrochloride $-1.5486^{38}$ ) is similar to the index of the co-monomer blend (mixture of BisGMA, TEGDMA, and HEMA - 1.47 to 1.59 (monomer) and 1.50-1.62 (polymer $)^{18}$ ). Because of the similar refractive index between the base resin and the material incorporated, the light energy availability is less susceptible to reduction, which probably contributed to the similar DC among groups. ${ }^{39}$. This is an advantage of PHMGH over the incorporation of antibaterial oxides/inorganic fillers, ${ }^{18}$ which usually have different refractive index, decreasing the DC. ${ }^{25}$ PHMGH did not affect the DC regardless the concentration evaluated. Besides having great mechanical properties, the sealants incorporated with PHMGH should provide stability to the material over time, as high DC also decreases the leaching of uncured monomers from the polymer matrix, improving biocompatibility. ${ }^{40}$

Although high DC may indicate satisfactory physico-chemical properties, ${ }^{26}$ the evaluation of mechanical and stability properties after solvent storage are necessary. The UTS analysis indicated no significant difference up to $1 \mathrm{wt}$.\% of PHMGH. With 2 wt.\% of PHMGH powder, agglomerates may form, which are not well-bonded to the organic matrix, decreasing the mechanical properties. ${ }^{17}$ Agglomerates in polymers do not constrain the surrounding matrix of deforming under mechanical load ${ }_{17}^{17}$ which may have led to the lower values for $\mathrm{G}_{2 \%}$ compared to $\mathrm{G}_{\mathrm{CTRL}}$. The lower concentrations of PHMGH promoted a better dispersion of the compound in the organic matrix, with less agglomeration of $\mathrm{PHMGH}$, resulting in the non-difference among $\mathrm{G}_{\mathrm{CTRL}}, \mathrm{G}_{0.5 \%}$ and $\mathrm{G}_{1 \%}$. However, despite the lower UTS observed for $\mathrm{G}_{2 \%}$, there was no difference for softening in solvent among the experimental resin sealants, and PHMGH groups reached higher KHN1 values. PHMGH powder could be pressed into the softer matrix rather than being plastically deformed, leading to the higher values of KHN1. After ethanolic solution storage, all experimental resin sealants showed lower values of Knoop hardness. This can be explained by the higher interaction between the solvent molecules and polymer chains on the resin surface rather than the covalent bonds in the polymer. ${ }^{41}$ One could expect that the increase in PHMGH incorporation would increase $\Delta \mathrm{KHN}$ due to the hydrochloride in its structure by increasing water sorption and solubility as occurred when hydrophilic monomers are incorporated in resins at higher concentration, increasing resin degradation. ${ }^{26}$ The addition of PHMGH did not increase the interaction with solvent molecules during immersion in the ethanolic solution and the high DC observed for all experimental resin sealants probably positively influenced these results. ${ }^{26}$ Thus, besides not having influenced the DC, the PHMGH incorporation probably did not negatively affect the crosslinking density, ${ }^{26}$ as there was no influence in the softening by the solvent regardless the concentration tested.

The contact angle and the SFE of polymers may also change due to the incorporation of fillers, as boron nitride nanotubes in dental adhesives, ${ }^{42}$ or different monomers, as quaternary alkylammonium in dental composites. ${ }^{43} \mathrm{~A}$ lower value of contact angle with water was obtained for $G_{2 \%}$ compared to $G_{0.5 \%}$ and $\mathrm{G}_{1 \%}$, with no significant differences between each PHMGH group and $G_{\text {CTRL }}$. Higher amounts of PHMGH would lead to lower contact angle values compared to $\mathrm{G}_{\text {CTRL }}$ due to PHMGH hydrophilicity. ${ }^{19}$ Also, there was a slightly but significant difference for SFE among groups, without significant difference between $G_{\text {CTRL }}$ and $G_{2 \%}$. Previous studies indicate higher cell attachment in surfaces with higher wettability. ${ }^{44}$ This theme is controversial, since another research shows no linear correlation between these properties and bacterial adhesion, ${ }^{45}$ turning the antibacterial activity evaluation indispensable. Even with the results observed for surface properties, the hydrophilic character of PHMGH did not influence the stability after the storage in ethanol:water solution compared to $\mathrm{G}_{\text {CTRL }}$. The non-difference in the softening in solvent, associated with the high values observed for DC up to $2 \mathrm{wt} . \%$ and the non-difference for UTS up to $1 \mathrm{wt} . \%$ may assist in the preservation of the polymer against hydrolytic degradation over time., 27,28

The experimental resin sealants with PHMGH were evaluated by direct contact inhibition and planktonic bacteria viability assays. The higher the 
PHMGH incorporation, the higher the antibacterial activity against biofilm formation on polymerized samples, with more than $60 \%$ of biofilm reduced with $\mathrm{G}_{2 \%}$ compared to $\mathrm{G}_{\mathrm{CTRL}}$. Dimethacrylates (TEGDMA, BisGMA and urethane dimethacrylate (UDMA)) commonly used for resin sealants composition do not present antibacterial activity. ${ }^{5}$ With the same purpose of antibacterial agents incorporation in adhesive systems,,$^{2,4,7}$ composite resins ${ }^{3}$ and glass ionomer cements ${ }^{46}$ resin sealants with PHMGH could prevent bacterial attachment and biofilm formation at tooth/ resin interface, where recurrent caries commonly occur, and act as an additional strategy against disease development. The planktonic bacteria inhibition assay showed no difference between $\mathrm{G}_{\mathrm{CTRL}}$ and $\mathrm{G}_{0.5 \% \text {, }}$ while $G_{1 \%}$ and $G_{2 \%}$ showed lower values of planktonic bacteria compared to $\mathrm{G}_{\text {CTRL }}$ and $\mathrm{G}_{0.5 \%}$. The decrease of planktonic bacteria in broth may be associated with the leaching of PHMGH from the polymer. ${ }^{47}$ It is also possible that the decrease of planktonic bacteria occurred due to the contact of the cells in broth with the surface of resin sealants, ${ }^{44}$ similar to a previous study with antibacterial monomers (quaternary ammonium compounds) that copolymerized with the base resin, inducing planktonic bacteria reduction in broth around the polymerized samples. ${ }^{2,7}$

The antibacterial activity of PHMGH observed in direct contact inhibition and planktonic bacteria viability assays occurred due to the increase of the cytoplasmic membrane permeability after adsorption and bonding to the negative charge of bacteria's surface, leading to leakage of intracellular constituents and cell death. ${ }^{21}$ In addition to the membrane disorganization and pore formation, ${ }^{21}$ guanidine compounds have shown to affect DNA and cellular proteins in Grampositive and Gram-negative bacteria. ${ }^{21}$ The selective DNA binding between guanidine molecules and bacteria chromosomes ${ }^{48}$ differentiates the antibacterial action of guanidine compounds from classical quaternary ammonium compounds, which commonly act only in bacteria wall and membrane. ${ }^{49}$ Regarding human cells, a previous study investigated the cytotoxicity of antiseptics, including guanidine molecules (as polyhexamethylene biguanide (PHMB) and octenide dihydrochloride (OCT)), chlorhexidine digluconate, and cetylpyridinium chloride against human fibroblasts. ${ }^{24}$ Guanidine molecules showed low cytotoxicity and high antibacterial activity. ${ }^{24}$ However, it is suggested that polyhexamethylene guanidine may be associated to toxic effects, including pulmonary fibrosis, when used in humidifier disinfectants. ${ }^{23}$ Thus, the results of this study should be used with caution and more cytotoxic tests should be performed.

The development of restorative materials with antibacterial activity is desirable for the improvement of the therapeutic effect. The present study presented the formulation of a new resin sealant with PHMGH as an antibacterial agent with reliable physico-chemical properties. In this way, PHMGH may be an alternative for long-lasting caries prevention of resin sealants.

\section{Conclusion}

PHMGH provided antibacterial activity for all resin sealant groups and the addition up to $1 \mathrm{wt} . \%$ showed reliable physico-chemical properties, maintaining the caries-protective effect of the resin sealant over time.

\section{Acknowledgement}

This study was financed in part by the Coordenação de Aperfeiçoamento de Pessoal de Nível Superior - Brasil (CAPES) - Finance Code 001 (scholarship).

\section{References}

1. Opdam NJ, van de Sande FH, Bronkhorst E, Cenci MS, Bottenberg P, Pallesen U, et al. Longevity of posterior composite restorations: a systematic review and meta-analysis. J Dent Res. 2014 Oct;93(10):943-9. https://doi.org/10.1177/0022034514544217

2. Collares FM, Leitune VCB, Franken P, Parollo CF, Ogliari FA, Samuel SMW. Influence of addition of

[2-(methacryloyloxy)ethyl]trimethylammonium chloride to an experimental adhesive. Braz Oral Res. 2017;31:e31.

http://dx.doi.org/10.1590/1807-3107bor-2017.vol31.0031 
- Antibacterial, chemical and physical properties of sealants with polyhexamethylene guanidine hydrochloride

3. Degrazia FW, Leitune VC, Garcia IM, Arthur RA, Samuel SM, Collares FM. Effect of silver nanoparticles on the physicochemical and antimicrobial properties of an orthodontic adhesive. J Appl Oral Sci. 2016 Jul-Aug;24(4):404-10. https://doi.org/10.1590/1678-775720160154

4. Garcia IM, Leitune VC, Visioli F, Samuel SM, Collares FM. Influence of zinc oxide quantum dots in the antibacterial activity and cytotoxicity of an experimental adhesive resin. J Dent. 2018 Jun;73:57-60. https://doi.org/10.1016/i.jdent.2018.04.003

5. Imazato S. Antibacterial properties of resin composites and dentin bonding systems. Dent Mater. 2003 Sep;19(6):449-57. https://doi.org/10.1016/S0109-5641(02)00102-1

6. Jung JH, Kim DH, Yoo KH, Yoon SY, Kim Y, Bae MK, et al. Dentin sealing and antibacterial effects of silver-doped bioactive glass/mesoporous silica nanocomposite: an in vitro study. Clin Oral Investig. 2019 Jan;23(1):253-66. https://doi.org/10.1007/s00784-018-2432-z

7. Schiroky PR, Leitune VC, Garcia IM, Ogliari FA, Samuel SM, Collares FM. Triazine compound as copolymerized antibacterial agent in adhesive resins. Braz Dent J. 2017 Mar-Apr;28(2):196-200. https://doi.org/10.1590/0103-6440201701346

8. Ahovuo-Saloranta A, Forss H, Walsh T, Nordblad A, Mäkelä M, Worthington HV. Pit and fissure sealants for preventing dental decay in permanent teeth. Cochrane Database Syst Rev. 2017 Jul;7:CD001830. https://doi.org/10.1002/14651858.CD001830.pub5

9. Holmgren C, Gaucher C, Decerle N, Doméjean S. Minimal intervention dentistry II: part 3. Management of non-cavitated (initial) occlusal caries lesions: non-invasive approaches through remineralisation and therapeutic sealants. Br Dent J. 2014 Mar;216(5):237-43. https://doi.org/10.1038/sj.bdj.2014.147

10. Khatri SG, Samuel SR, Acharya S, Patil S, Madan K. Retention of moisture-tolerant and conventional resin-based sealant in six- to nineyear-old children. Pediatr Dent. 2015 Jul-Aug;37(4):366-70.

11. Mickenautsch S, Yengopal V. Validity of sealant retention as surrogate for caries prevention-a systematic review. PLoS One. 2013 Oct;8(10):e77103. https://doi.org/10.1371/journal.pone.0077103

12. Güçlü ZA, Dönmez N, Hurt AP, Coleman NJ. Characterisation and microleakage of a new hydrophilic fissure sealant - UltraSeal XT ${ }^{\circledR}$ hydro $^{\text {TM }}$. J Appl Oral Sci. 2016 Jul-Aug;24(4):344-51. https://doi.org/10.1590/1678-775720160010

13. Hamilton MF, Otte AD, Gregory RL, Pinal R, Ferreira-Zandoná A, Bottino MC. Physicomechanical and antibacterial properties of experimental resin-based dental sealants modified with nylon-6 and chitosan nanofibers. J Biomed Mater Res B Appl Biomater. 2015 Nov; 103(8):1560-8. https://doi.org/10.1002/jbm.b.33342

14. Kaga M, Kakuda S, Ida Y, Toshima H, Hashimoto M, Endo K, et al. Inhibition of enamel demineralization by buffering effect of S-PRG filler-containing dental sealant. Eur J Oral Sci. 2014 Feb;122(1):78-83. https://doi.org/10.1111/eos.12107

15. Yang SY, Kwon JS, Kim KN, Kim KM. Enamel Surface with Pit and Fissure Sealant Containing 45 S5 Bioactive Glass. J Dent Res. 2016 May;95(5):550-7. https://doi.org/10.1177/0022034515626116

16. Bagheri M, Pilecki P, Sauro S, Sherriff M, Watson TF, Hosey MT. An in vitro investigation of pre-treatment effects before fissure sealing. Int J Paediatr Dent. 2017 Nov;27(6):514-22. https://doi.org/10.1111/ipd.12290

17. Belli R, Kreppel S, Petschelt A, Hornberger H, Boccaccini AR, Lohbaver U. Strengthening of dental adhesives via particle reinforcement. J Mech Behav Biomed Mater. 2014 Sep;37:100-8. https://doi.org/10.1016/i.jmbbm.2014.05.007

18. Leitune VC, Collares FM, Takimi A, de Lima GB, Petzhold CL, Bergmann CP, et al. Niobium pentoxide as a novel filler for dental adhesive resin. J Dent. 2013 Feb;41(2):106-13. https://doi.org/10.1016/i.jdent.2012.04.022

19. Oulé MK, Quinn K, Dickman M, Bernier AM, Rondeau S, De Moissac D, et al. Akwaton, polyhexamethylene-guanidine hydrochloridebased sporicidal disinfectant: a novel tool to fight bacterial spores and nosocomial infections. J Med Microbiol. $2012 \mathrm{Oct} ; 61(\mathrm{Pt}$ 10):1421-7. https://doi.org/10.1099/jmm.0.047514-0

20. Zhou Z, Wei D, Lu Y. Polyhexamethylene guanidine hydrochloride shows bactericidal advantages over chlorhexidine digluconate against ESKAPE bacteria. Biotechnol Appl Biochem. 2015 Mar-Apr;62(2):268-74. https://doi.org/10.1002/bab.1255

21. Zhou ZX, Wei DF, Guan Y, Zheng AN, Zhong JJ. Damage of Escherichia coli membrane by bactericidal agent polyhexamethylene guanidine hydrochloride: micrographic evidences. J Appl Microbiol. 2010 Mar;108(3):898-907. https://doi.org/10.1111/j.1365-2672.2009.04482.x

22. Choi H, Kim KJ, Lee DG. Antifungal activity of the cationic antimicrobial polymer-polyhexamethylene guanidine hydrochloride and its mode of action. Fungal Biol. 2017 Jan;121(1):53-60. https://doi.org/10.1016/i.funbio.2016.09.001

23. Park K. An analysis of a humidifier disinfectant case from a toxicological perspective. Environ Health Toxicol. 2016 Jul;31:e2016013. https://doi.org/10.5620/eht.e2016013

24. Müller G, Kramer A. Biocompatibility index of antiseptic agents by parallel assessment of antimicrobial activity and cellular cytotoxicity. J Antimicrob Chemother. 2008 Jun;61(6):1281-7. https://doi.org/10.1093/jac/dkn125

25. Garcia IM, Leitune VC, Ferreira CJ, Collares FM. Tantalum oxide as filler for dental adhesive resin. Dent Mater J. 2018 Nov;37(6):897903. https://doi.org/10.4012/dmi.2017-308

26. Collares FM, Ogliari FA, Zanchi CH, Petzhold CL, Piva E, Samuel SM. Influence of 2-hydroxyethyl methacrylate concentration on polymer network of adhesive resin. J Adhes Dent. 2011 Apr;13(2):125-9. 
27. Rodrigues SB, Collares FM, Leitune VC, Schneider LF, Ogliari FA, Petzhold CL, et al. Influence of hydroxyethyl acrylamide addition to dental adhesive resin. Dent Mater. 2015 Dec;31(12):1579-86. https://doi.org/10.1016/i.dental.2015.10.005

28. Garcia IM, Leitune VC, Kist TL, Takimi A, Samuel SM, Collares FM. Quantum dots as nonagglomerated nanofillers for adhesive resins. J Dent Res. 2016 Nov;95(12):1401-7. https://doi.org/10.1177/0022034516656838

29. Altmann AS, Collares FM, Leitune VC, Arthur RA, Takimi AS, Samuel SM. In vitro antibacterial and remineralizing effect of adhesive containing triazine and niobium pentoxide phosphate inverted glass. Clin Oral Investig. 2017 Jan;21(1):93-103. https://doi.org/10.1007/s00784-016-1754-y

30. Degrazia FW, Genari B, Leitune VC, Arthur RA, Luxan SA, Samuel SM, et al. Polymerisation, antibacterial and bioactivity properties of experimental orthodontic adhesives containing triclosan-loaded halloysite nanotubes. J Dent. 2018 Feb;69:77-82. https://doi.org/10.1016/j.jdent.2017.11.002

31. Genari B, Leitune VC, Jornada DS, Camassola M, Arthur RA, Pohlmann AR, et al. Antimicrobial effect and physicochemical properties of an adhesive system containing nanocapsules. Dent Mater. 2017 Jun;33(6):735-42. https://doi.org/10.1016/i.dental.2017.04.001

32. Righolt AJ, Jevdjevic M, Marcenes W, Listl S. Global-, regional-, and country-level economic impacts of dental diseases in 2015. J Dent Res. 2018 May;97(5):501-7. https://doi.org/10.1177/0022034517750572

33. Ahovuo-Saloranta A, Forss H, Walsh T, Hiiri A, Nordblad A, Mäkelä M, et al. Sealants for preventing dental decay in the permanent teeth. Cochrane Database Syst Rev. 2013 Mar;3(3):CD001830. https://doi.org/10.1002/14651858.CD001830.pub4

34. Kühnisch J, Mansmann U, Heinrich-Weltzien R, Hickel R. Longevity of materials for pit and fissure sealing -results from a meta-analysis. Dent Mater. 2012 Mar;28(3):298-303. https://doi.org/10.1016/i.dental.2011.11.002

35. Borges BC, Bezerra GV, Mesquita JA, Pereira MR, Aguiar FH, Santos AJ, et al. Effect of irradiation times on the polymerization depth of contemporary fissure sealants with different opacities. Braz Oral Res. 2011 Mar-Apr;25(2):135-42. https://doi.org/10.1590/S1806-83242011000200007

36. Imazato S, Kinomoto Y, Tarumi H, Ebisu S, Tay FR. Antibacterial activity and bonding characteristics of an adhesive resin containing antibacterial monomer MDPB. Dent Mater. 2003 Jun;19(4):313-9. https://doi.org/10.1016/S0109-5641(02)00060-X

37. Vidal ML, Rego GF, Viana GM, Cabral LM, Souza JP, Silikas N, et al. Physical and chemical properties of model composites containing quaternary ammonium methacrylates. Dent Mater. 2018 Jan;34(1):143-51. https://doi.org/10.1016/i.dental.2017.09.020

38. De Paula GF, Netto GI, Mattoso LHC. Physical and chemical characterization of poly(hexamethylene biguanide) hydrochloride. Polymers (Basel). 2011 Jun;3(2):928-41. https://doi.org/10.3390/polym3020928

39. Schulz H, Schimmoeller B, Pratsinis SE, Salz U, Bock T. Radiopaque dental adhesives: dispersion of flame-made Ta2O5/SiO2 nanoparticles in methacrylic matrices. J Dent. 2008 Aug;36(8):579-87. https://doi.org/10.1016/i.jdent.2008.04.010

40. Goldberg M. In vitro and in vivo studies on the toxicity of dental resin components: a review. Clin Oral Investig. 2008 Mar;12(1):1-8. https://doi.org/10.1007/s00784-007-0162-8

41. Schneider LF, Moraes RR, Cavalcante LM, Sinhoreti MA, Correr-Sobrinho L, Consani S. Cross-link density evaluation through softening tests: effect of ethanol concentration. Dent Mater. 2008 Feb;24(2):199-203. https://doi.org/10.1016/j.dental.2007.03.010

42. Degrazia FW, Leitune VC, Samuel SM, Collares FM. Boron nitride nanotubes as novel fillers for improving the properties of dental adhesives. J Dent. 2017 Jul;62:85-90. https://doi.org/10.1016/i.jdent.2017.05.013

43. Burviana T, Melinte $V$, Popa ID, Burviana EC. New urethane oligodimethacrylates with quaternary alkylammonium for formulating dental composites. J Mater Sci Mater Med. 2014 Apr;25(4):1183-94. https://doi.org/10.1007/s10856-014-5141-4

44. Liu Y, Zhao Q. Influence of surface energy of modified surfaces on bacterial adhesion. Biophys Chem. 2005 Aug; 117(1):39-45. https://doi.org/10.1016/j.bpc.2005.04.015

45. Almaroof A, Niazi SA, Rojo L, Mannocci F, Deb S. Influence of a polymerizable eugenol derivative on the antibacterial activity and wettability of a resin composite for intracanal post cementation and core build-up restoration. Dent Mater. 2016 Jul;32(7):929-39. https://doi.org/10.1016/j.dental.2016.04.001

46. Hatunoğlu E, Oztürk F, Bilenler T, Aksakallı S, Simşek N. Antibacterial and mechanical properties of propolis added to glass ionomer cement. Angle Orthod. 2014 Mar;84(2):368-73. https://doi.org/10.2319/020413-101.1

47. van de Lagemaat M, Grotenhuis A, van de Belt-Gritter B, Roest S, Loontjens TJ, Busscher HJ, et al. Comparison of methods to evaluate bacterial contact-killing materials. Acta Biomater. 2017 Sep;59(59):139-47. https://doi.org/10.1016/i.actbio.2017.06.042

48. Chindera K, Mahato M, Sharma AK, Horsley H, Kloc-Muniak K, Kamaruzzaman NF, et al. The antimicrobial polymer PHMB enters cells and selectively condenses bacterial chromosomes. Sci Rep. 2016 Mar;6(6):23121. https://doi.org/10.1038/srep23121

49. Makvandi P, Jamaledin R, Jabbari M, Nikfarjam N, Borzacchiello A. Antibacterial quaternary ammonium compounds in dental materials: A systematic review. Dent Mater. 2018 Jun;34(6):851-67. https://doi.org/10.1016/i.dental.2018.03.014 